\title{
lodide symporter gene expression in normal and transformed rat thyroid cells
}

\author{
Francesco Trapasso, Rodolfo Iuliano, Eusebio Chiefari, Franco Arturi, Antonella Stella, Sebastiano Filetti, \\ Alfredo Fusco and Diego Russo ${ }^{1}$ \\ Dipartimento di M edicina Sperimentale e Clinica, Facoltà di M edicina e Chirurgian and ${ }^{1}$ Cattedra di Farmacologia, Facoltà di Farmacia, Università di \\ Catanzaro, 88100 Catanzaro, Italy
}

(Correspondence should be addressed to D Russo, Dipartimento di M edicina Sperimentale e Clinica, Via T. Campanella, 115, 88100 Catanzaro, Italy)

\begin{abstract}
Objective: Decrease or loss of the $\mathrm{Na}^{+} / \mathrm{I}^{-}$symporter (NIS) activity profoundly affects the suitability of the use of radioiodine to detect or treat metastatic thyroid tissues. The aim of our study was to verify whether specific oncogene abnormalities were responsible for the alteration in NIS activity in thyroid cells. Design and methods: Expression of the NIS gene was investigated by Northern blot analysis in normal and in some oncogene-transformed cell lines with different degrees of malignancy which had lost the iodide uptake ability.

Results: NIS gene expression was up-regulated by TSH in a dose-dependent and time-dependent way in normal PC Cl 3 cells. The same effect was observed by activating the CAMP-dependent pathway by forskolin. Conversely, insulin and 12-0-tetradecanoylphorbol-13-acetate (TPA) showed a partial inhibitory effect on NIS gene expression. The oncogene-transformed cell lines PC v-erbA, PC HaMSV, PC v-raf, and PC E1A cells showed reduced NIS mRNA levels compared with the normal PC Cl 3 cells. Conversely, an almost complete absence of NIS gene expression was found in PC RET/PTC, PC KiMSV, PC p53 $3^{143 a l a}$, and PC PyMLV cell lines.

Conclusions: Our data show that oncogene activation could play a role in affecting the iodide uptake ability in thyroid tumoral cells; different mechanisms are involved in the oncogene-dependent loss of NIS activity in transformed thyroid cells.
\end{abstract}

European Journal of Endocrinology $140447-451$

\section{Introduction}

lodide uptake is a fundamental step in the synthesis of thyroid hormones. It occurs against its electrochemical gradient through an active/ energy depending transport mechanism mediated by the $\mathrm{Na}^{+} / \mathrm{I}^{-}$symporter (NIS) (1). Iodine trapping is reduced or suppressed in thyroid cancer cells (2), however the mechanism underlying the block of this thyroid differentiated function is still unknown.

The recent cloning of the NIS gene (3) allowed the investigation of gene expression in thyroid pathologies. All of the studies on human thyroid tumors except one (4) showed that NIS mRNA expression is downregulated or absent in the tumors (5-7). Such data correlate with a reduced amount of the NIS protein, detected by immunohistochemistry in tumoral thyroid tissues $(8,9)$. Since the ability of iodine concentration by the tumoral cell is a fundamental prerequisite for the use of radioiodine as a diagnostic and therapeutic tool for the management of thyroid carcinomas (10), assessment of the molecular basis underlying the presence of the loss of such a function represents an important goal.
In this study, we focused our attention on the correlation between the presence of NIS gene expression and the degree of dedifferentiation of transformed thyrocytes expressing different oncogenes. For this purpose, we analysed the presence of NIS mRNA transcript in normal and transformed $\mathrm{PC} \mathrm{Cl} 3$ rat thyroid cells (11-15). The advantage of such a model is offered by the availability of different cell lines with various degrees of malignancy, obtained by infection with murine retroviruses expressing oncogenes (PC RET/PTC, KiMSV, HaMSV, v-raf, v-erbA, and PyM LV) or transfection with oncogenes (p53 $3^{143 a l a}$, E1A) (11-15). It is remarkable that some of these oncogenes were found to be activated in human thyroid tumors in vivo (16), thus representing an in vitro counterpart of the multi-step model of thyroid tumorigenesis.

\section{Materials and methods}

\section{Cell culture}

The PC $\mathrm{Cl} 3$ cell line is a thyroid epithelial cell line derived from 18-month-old normal Fischer rats (11). The cells 
were grown in modified Ham's F-12 medium (Sigma Chemical Co., Sigma-Aldrich S.z.I., Milano, Italy) supplemented with $5 \%$ calf serum (GIBCO, Life Technologies Limited, UK) and six growth factors (thyrotrophin (TSH), insulin, hydrocortisone, human transferrin, somatostatin, and glycyl-L-histidyl-L-lysine acetate) (Sigma Chemical Co.), as previously described (11). PC RET/ PTC, KiMSV, HaMSV, v-raf, v-erbA, p53 ${ }^{143 a l a}$, E1A, and PyMLV were grown in the same medium (11-15).

\section{lodide uptake}

lodide uptake was performed as previously described by Trapasso et al. (15). Briefly, $1 \times 10^{6}$ cells for each cell type were diluted in $1 \mathrm{ml}$ culture medium in an Eppendorf tube and heated in a water bath at $37^{\circ} \mathrm{C}$ for $5 \mathrm{~min}$. After addition of $10^{6}$ counts of ${ }^{125} \mathrm{I}$, the cells were subsequently incubated at $37^{\circ} \mathrm{C}$ for $30 \mathrm{~min}$ with continuous shaking and were then centrifuged for $5 \mathrm{~min}$. The supernatant was removed and the pellet was washed with culture medium and counted for 1 min in a gamma counter.

\section{RNA extraction, Northern blot analysis and reverse transcription (RT)-PCR}

Total RNA was extracted by RNAfast Isolation System (Molecular System, San Diego, CA, USA) according to the manufacturer's instructions. Northern blot and hybridization procedures were performed according to standard procedures (17). The labelled 1-2046 NIS rat probe was obtained by EcoRI-Hindlll digestion of the full-length rat NIS CDNA. A rat glyceraldehyde-3phosphate-dehydrogenase (GAPDH) probe was used to ascertain equal RNA loading (15). Quantification was achieved by densitometric scanning.

The cDNA was synthesized from $1 \mu \mathrm{g}$ total RNA according to the protocol of themanufacturer (Boeh ringer Mannheim Italy SpA, Monza, Italy). The mixture was incubated at $25^{\circ} \mathrm{C}$ for $10 \mathrm{~min}, 42^{\circ} \mathrm{C}$ for $60 \mathrm{~min}$, heated to $99^{\circ} \mathrm{C}$ for $5 \mathrm{~min}$, and then stored at $-20^{\circ} \mathrm{C}$. PCR amplification was performed using $5 \mu \mathrm{l}$ CDNA, as previously described (18). Briefly, samples were subjected to 41 cycles of amplification and PCR conditions were as follows: denaturation at $94^{\circ} \mathrm{C}$ (1 min), annealing at $58^{\circ} \mathrm{C}(1 \mathrm{~min})$ and extension at $72{ }^{\circ} \mathrm{C}$ (1 min) for 40 cycles; the last cycle was $72^{\circ} \mathrm{C}$ for 7 min (1 cycle). Ten out of the fifty microlitres of the amplification products were then analysed on $1.5 \%$ Tris-borate-EDTA agarose gel containing ethidium bromide. Primer oligonucleotides for the NIS gene were: 5' primer, 5'-GTGCCGACGATTCTTTACCG-3' and 3' primer, 5'-AAGTACTGCAGCGTCCCG-3'. The amplification yielded a 285 base pair DNA product corresponding to fragment 237-522 according to the published sequence of the rat NIS gene (3). All primers were from GENOSYS (Cambridge, UK).

\section{Results}

In normal PC Cl 3 cells, NIS mRNA is up-regulated by TSH in a time-dependent (Fig. 1a) and dose-dependent
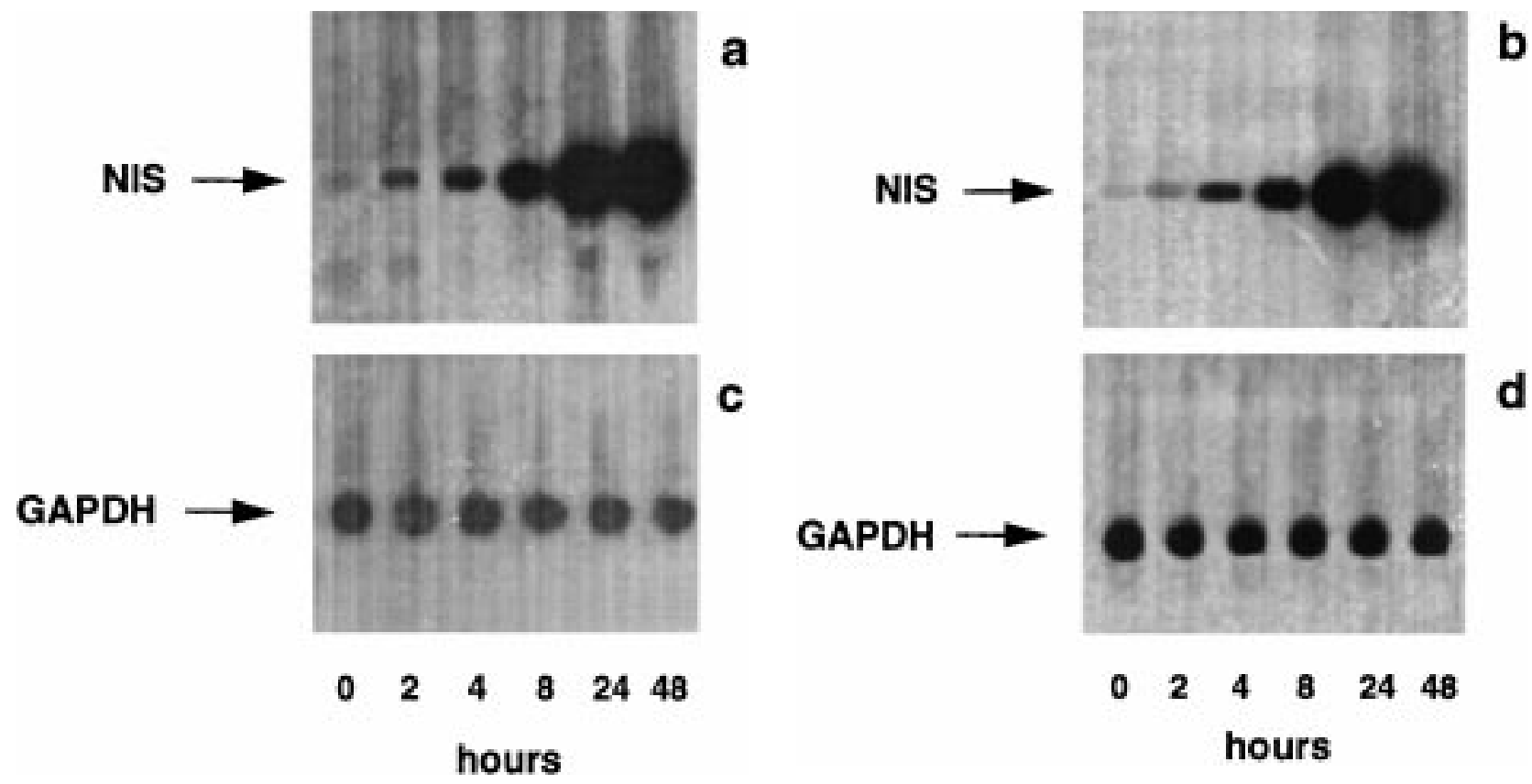

Figure 1 Time-course of (a) TSH (1 mU/ml) and (b) forskolin $\left(10^{-5} \mathrm{~mol} / \mathrm{l}\right)$ stimulation of NIS mRNA expression in normal PC CI 3 cells. Cells were starved of TSH for seven days before stimulation. Northern blot analysis was performed as described in Materials and methods. The amount of RNA was ascertained by hybridization with a GAPDH probe (c, d). Data are representative of three different experiments. 


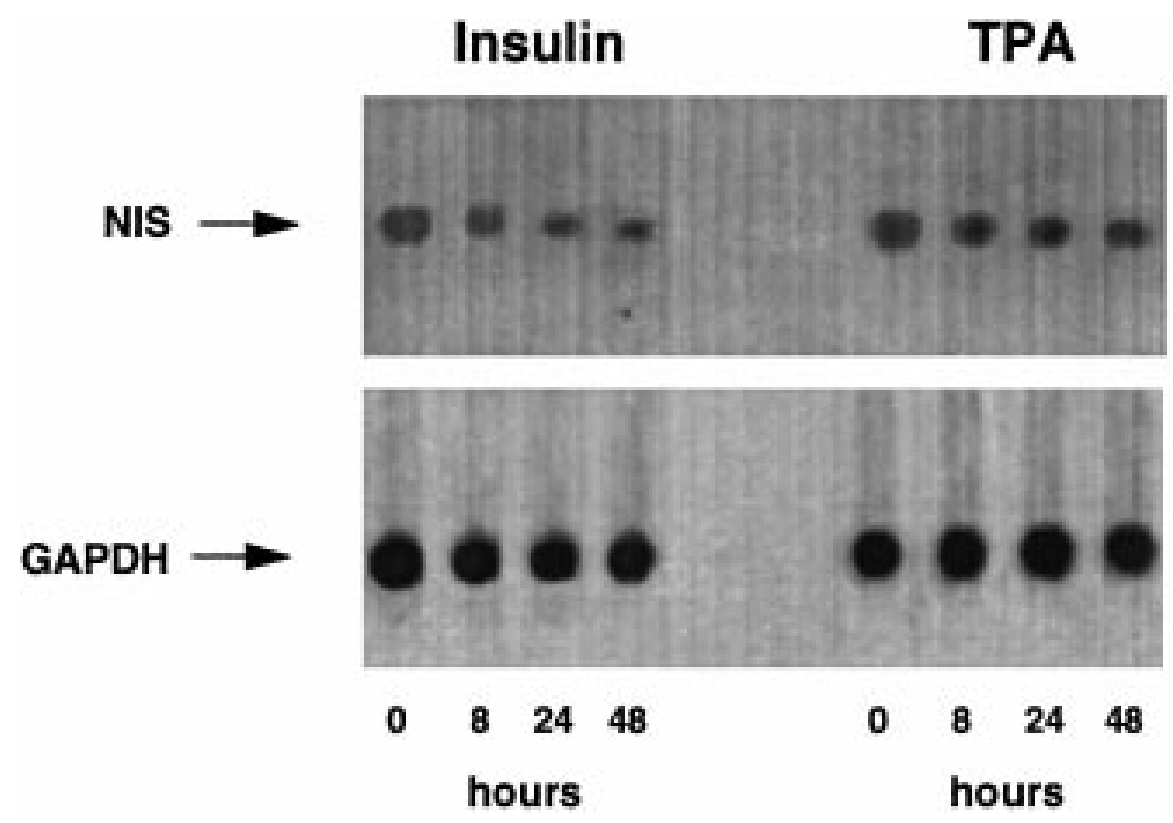

Figure 2 Time-course of insulin $\left(10^{-7} \mathrm{~mol} / \mathrm{l}\right)$ and TPA $(16 \mathrm{ng} / \mathrm{ml})$ stimulation of NIS mRNA expression in normal PC CI 3 cells. Cells were starved of insulin for seven days before stimulation. Northern blot analysis was performed as described in Materials and methods. The amount of RNA was ascertained by hybridization with a GAPDH probe. Data are representative of three different experiments.

manner (data not shown). After TSH stimulation the NIS mRNA levels were increased approximately sixfold over controls. The effect appears to be cAMP dependent, because it was fully reproduced by forskolin stimulation (Fig. 1b). Interestingly, stimulators acting through CAMP-independent pathways, such as insulin and 120-tetradecanoylphorbol-13-acetate (TPA), had no effect on enhancing NIS mRNA levels; on the contrary, they showed a partial inhibitory effect (approximately twofold decrease over basal) (Fig. 2).

Transformation by all the oncogenes tested determined the complete loss of iodide uptake function (Table 1). It occurred also in those clones with a low degree of malignancy (15) and irrespective of the expression of other thyroid-specific markers (Table 1).

To study the role of the oncogenes in the expression of the NIS gene, these cell lines were analysed by Northern blot for the presence of specific NIS MRNA transcript. The results are shown in Fig. 3. NIS mRNA levels were found partially reduced in PC v-erbA, HaMSV, v-raf and E1A cells and almost absent in PC RET/PTC, KiMSV, p53 $3^{143 a l a}$ and PyMLV cell clones when compared with the levels detected in normal PC Cl 3 cells (Fig. 3). In the PC RET/PTC, KiMSV, p53 ${ }^{143 a l a}$ and PyMLV cell clones

Table 1 lodide uptake and other features of normal and transformed PC cells.

\begin{tabular}{lcccc}
\hline Cell lines & Oncogene & $\begin{array}{c}\text { TSH } \\
\text { dependency }\end{array}$ & $\begin{array}{c}\text { Tg mRNA } \\
\text { expression }\end{array}$ & $\begin{array}{c}\text { lodide } \\
\text { uptake }^{\text {c }}\end{array}$ \\
\hline PC Cl 3 & - & + & +++ & +++ \\
PC $v$-erbA & $v$-erbA & + & +++ & - \\
PC E1A & AD5 E1A & $+/-$ & - & - \\
PC PyMLV & Middle T & $+/-$ & - & - \\
PC RET/PTC & RET/PTC & $+/-$ & - & - \\
PC KiMSV & $v$-ras Ki & - & $+l--$ & - \\
PC HaMSV & $v$-ras Ha & - & - & - \\
PC $v$-raf & $v$-raf & - & - & - \\
PC p53 & & - & &
\end{tabular}

\footnotetext{
${ }^{\text {a }}$ Cell growth dependence by TSH: +, total; +/- partial; - , absent.

${ }^{\mathrm{b}}$ Assayed by Northern blot: +++ , physiological Tg mRNA levels; + +-- , less than $20 \%$ vs normal PC cells; - , absence of Tg mRNA.

c 125 I incorporation in $10^{6}$ cells:,$+++ \sim 30 \%$ of total ${ }^{125}$ I added to the medium; - , less than $1 \%$. Data on TSH dependent growth and Tg expression are from Fusco et al. (11), Santoro et al. (12), Berlingieri et al. (13), Battista et al. (14) and Trapasso et al. (15).

${ }^{*} \mathrm{PC} \mathrm{p53^{143ala }}$ is a cellular clone obtained by transfecting PC Cl 3 cells with the antioncogene p53 carrying a Val $\rightarrow$ Ala mutation at amino acid 143 which determines the loss of the biochemical activities of wild type p53 protein (14).
} 

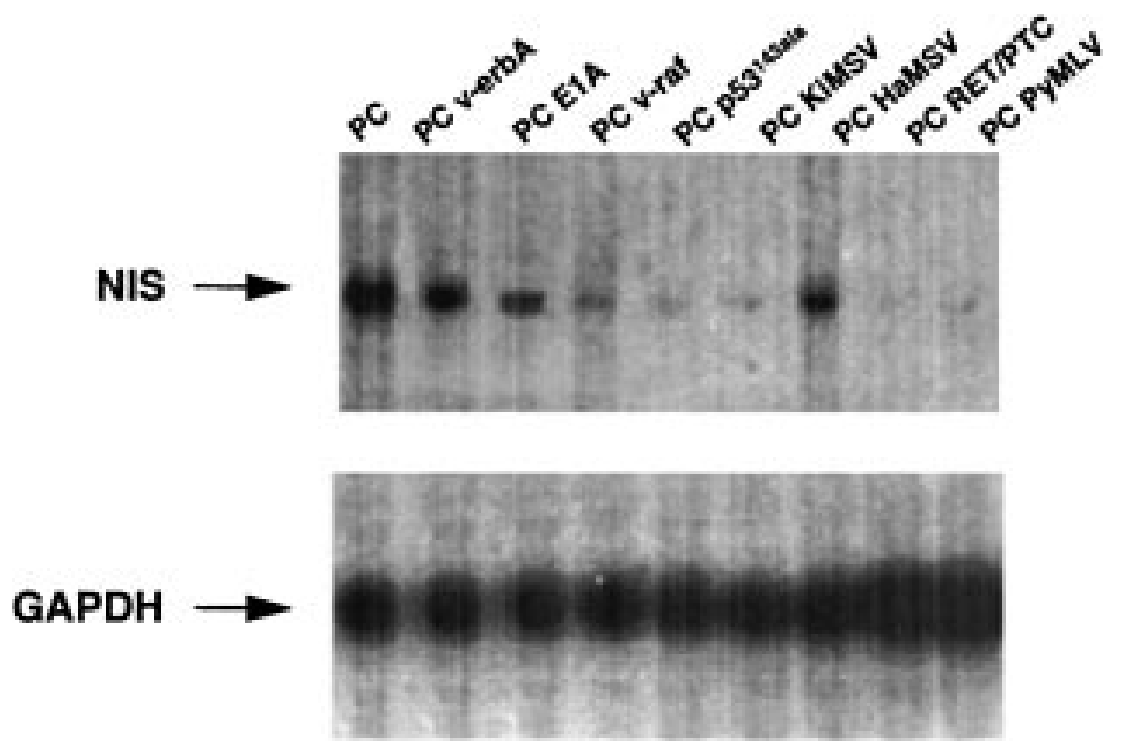

Figure 3 NIS mRNA levels in PC cells expressing RET/PTC, v-ras Ki (PC KiMSV), v-ras Ha (PC HaMSV), v-raf, v-erb A, p53 ${ }^{143 a l a}$, E1A, PyMLV oncogenes. Northern blot analysis was performed as described in Materials and methods. The amount of RNA was ascertained by hybridization with a GAPDH probe. Data are representative of three different experiments.

the RT-PCR analysis showed a faint band after 40 cycles of amplification (data not shown).

\section{Discussion}

The presence of the functional integrity of the NIS in malignant thyroid cells allows an adequate radioiodine uptake to detect and eradicate the neoplastic thyroid tissue. However, a variety of iodine metabolism abnormalities has been demonstrated in thyroid cancer tissue, including defects in the transport and in the organification process $(2,19)$. These defects are presumably responsible for the low or absent radioiodine uptake detected in some malignant thyroid cells. Preliminary studies indicated that changes in NIS gene expression occur in some differentiated thyroid carcinomas (4-7), independent of the expression of other thyroid specific transcripts, such as TSH receptor (TSH-R), thyroglobulin $(\mathrm{Tg})$ and thyroid peroxidase (TPO). It suggests that the expression of the iodide symporter, Tg, TSH-R and TPO genes is regulated by distinct molecular mechanisms or, alternatively, may have a different pattern of sensitivity to the mechanisms of oncogen ic transformation. Similar discrepancies have been found in vitro: oncogenetransformed rat thyroid cells lack iodine uptake, whereas Tg, TPO and TSH-R gene expression is present to variable extents (15, D Russo, D Foti, G Grosso \& S Filetti, unpublished data).

In this study we investigated the molecular mechanisms underlying the loss of iodide uptake function to verify whether the loss of NIS expression correlated with a specific oncogenic pathway activation. The $\mathrm{PC} \mathrm{Cl} 3$ rat thyroid cells represent a unique model for the study of thyroid epithelial cell growth and differentiation, because they retain all the markers of thyroid differentiation in vitro, i.e. thyroglobulin synthesis, ability in iodine trapping and TSH-dependence for growth (11, 12). Moreover, the oncogene-transformed PC cell lines show different degrees of malignancy and differentiation $(11-15,20)$.

In PC Cl 3 cells we found that NIS mRNA expression is up-regulated by TSH and forskolin, whileinsulin and TPA, acting through activation of tyrosine kinase and protein kinase $C$ pathways respectively, have an opposite effect. These data are consistent with those obtained on FRTL-5 (21) or human (22) thyroid cells, confirming that in cultured thyrocytes NIS gene expression is exclusively dependent on the TSH-R-CAMP pathway. Therefore, as observed in vivo (see above), regulation of NIS expression at the mRNA level appears to be different from other thyroid-specific markers. Other factors, including iodide, retinoic acid and transforming growth factor- $\beta$, also participate in NIS gene and protein expression regulation, as assessed in FRTL-5 and human thyroid cells in vitro and in dog and rat thyroid in vivo $(6,23-26)$.

Interesting results have been obtained by investigating NIS expression in transformed PC cell lines. PC RET/ PTC, KiMSV, p53 $3^{143 a l a}$ and PyMLV cells showed very low NIS-specific mRNA levels, suggesting the presence of an alteration occurring at an early transcriptional step. For PC KiMSV cells, it may be related to absence of expression of thyroid transcription factor 1 , for which a cis-acting element has been identified in the rat NIS promoter (27), whereas a secondary effect of transformed phenotype may be hypothesized in the case of the PC RET/PTC clone (28).

In PC v-erbA, HaMSV, v-raf and E1A cell clones, NIS transcript was maintained, although to a reduced 
extent, suggesting the occurrence of a post-transcriptional event responsible for the loss of iodide uptake function. Thus, different on cogenic pathway activation (PyMLV, p53 ${ }^{143 a l a}$, ras) may determine the same effect, and the same oncogenic pathway (v-ras Ha, v-ras Ki) may produce different alterations on the transcriptional regulation of NIS gene. Extension of the study at the level of protein expression, associated with the in vivo counterpart of these cellular models (thyroid tumors expressing RET/PTC or ras oncogene) will help to clarify the molecular mechanisms underlying iodine trapping defects in thyroid tumorigenesis.

\section{Acknowledgements}

This work was supported by the Associazione Italiana per la Ricerca sul Cancro (AIRC) (to S Filetti and A Fusco). $F$ Trapasso and A Stella were recipients of FIRC fellowships. $R$ Iuliano was the recipient of a grant from the Associazione Partenopea Ricerche Oncologiche (APRO). F Arturi was the recipient of a Dottorato di ricerca in Basi molecolari dell'azione ormonale fellowship at University of Catania.

\section{References}

1 Levy 0 \& Carrasco N. Structure and function of the thyroid iodide transporter and its implications for thyroid disease. Current Opinion in Endocrinology and Diabetes 19974 364-370.

2 Thomas-Morvan $C$, Carayon $P$, Schlumberger $M$, Vignal $A \&$ Tubiana M. Thyrotropin stimulation of adenylate cyclase and iodine uptake in human differentiated thyroid cancer. Acta Endocrinologica 1982101 25-31.

3 Dai G, Levy 0 \& Carrasco N. Cloning and characterization of the thyroid iodide symporter. Nature 1996 379 458-460.

4 Saito T, Endo T, Kawaguchi A, Ikeda M, Katoh R, Kawaoi A et al. Increased expression of the sodium/iodide symporter in papillary thyroid carcinomas. Journal of Clinical Investigation 1998101 $1296-1300$.

5 Smanik PA, Ryu K-Y, Theil KS, Mazzaferri EL \& Jhiang SM. Expression, exon-intron organization, and chromosome mapping of the human sodium iodide symporter. Endocrinology 1997138 3555-3558.

6 Schmutzler C, Winzer R, Meissner-Weigl J \& Kohrle J. Retinoic acid increases sodium/iodide symporter mRNA levels in human thyroid cancer cell lines and suppresses expression of functional symporter in nontransformed FRTL-5 rat thyroid cells. Biochemical and Biophysical Research Communication 1997240 832-838.

7 Arturi F, Russo D, Schlumberger M, DuVillard JA, Caillou B, Vigneri $\mathrm{P}$ et al. Iodide symporter gene expression in human thyroid tumors. Journal of Clinical Endocrinology and M etabolism 199882 2493-2496.

8 Jhiang SM, Cho J-Y, Ryu K-Y, DeYoung BR, Smanik PA, McGaughy VR et al. An immunohistochemical study of $\mathrm{Na}^{+} / \mathrm{I}^{-}$ symporter in human thyroid tissues and salivary gland tissues. Endocrinology 1998139 4416-4419.

9 Caillou B, Troalen F, Baudin E, Talbot M, Filetti S, Schlumberger M et al. Immunohistochemical detection of the $\mathrm{Na}^{+} / \mathrm{I}^{-}$symporter in human thyroid tissues. Journal of Clinical Endocrinology and M etabolism 199883 4102-4106.

10 Mazzaferri EL. Carcinoma of follicular epithelium: radioiodine and other treatment outcomes. In The Thyroid: a Fundamental and Clinical text, edn 7, pp 43-54. Eds EL Braverman \& RD Utiger. Philadel phia: Lippincott-Raven Press, 1996.

11 Fusco A, Berlingieri MT, Di Fiore PP, Portella G, Grieco M \& Vecchio $G$. One- and two-step transformations of rat thyroid epithelial cells by retroviral oncogenes. Molecular and Cellular Biology 19877 3365-3370.

12 Santoro M, Melillo RM, Grieco M, Berlingieri MT, Vecchio G \& Fusco A. The TRK and RET tyrosine kinase oncogenes cooperate with ras in the neoplastic transformation of a rat epithelial cell line. Cell Growth and Differentiation 19934 77-84.

13 Berlingieri MT, Santoro M, Battaglia C, Grieco M \& Fusco A. The adenovirusE1A geneblocks the differentiation of a thyroid epithelial cell line, however the neoplastic phenotype is achieved only after cooperation with other oncogenes. Oncogene 19938 249-255.

14 Battista S, Martelli ML, Fedele M, Chiappetta G, Trapasso F, De Vita $\mathrm{G}$ et al. A mutated p53 gene alters thyroid cell differentiation. Oncogene 199511 2029-2037.

15 Trapasso F, Martelli ML, Battaglia C, Angotti E, Mele E, Stella A et al. The $v$-erb $A$ oncogene selectively inhibits iodide uptake in rat thyroid cells. Oncogene 199612 1879-1888.

16 Farid NR, Shi Y \& Zou M. Molecular basis of thyroid cancer. Endocrine Review 199415 202-232.

17 Sambrook J, Fritch EF \& Maniatis T. Molecular Cloning: a Laboratory M anual, edn 2. Cold Spring Harbor Laboratory Press. New York: Cold Spring Harbor, 1989.

18 Arturi F, Russo D, Giuffrida D, Ippolito A, Perrotti N, Vigneri R et al. Early diagnosis by genetic analysis of differentiated thyroid cancer metastases in small lymph nodes. Journal of Clinical Endocrinology and M etabolism 199782 1638-1641.

19 Schlumberger M, Parmentier C, de Vathaire F \& Tubiana M. ${ }^{131}$ I and external radiation in the treatment of local and metastatic thyroid cancer. In Thyroid Disease: Endocrinology, Surgery, Nuclear M edicine, and Radiotherapy, pp 537-552. Ed SA Falk. New York: Raven Press Ltd, 1990.

20 Berlingieri MT, Portella G, Grieco M, Santoro M \& Fusco A. Cooperation between the polyomavirus middle-T-antigen gene and the human c-myc oncogene in a rat thyroid epithelial differentiated cell line: model of in vitro progression. M olecular and Cellular Biology 19888 226-230.

21 Kogai T, Endo T, Saito T, Miyazaki A, Kawaguchi A \& Onaya T. Regulation by thyroid-stimulating hormone of sodium/iodide symporter gene expression and protein levels in FRTL-5 cells. Endocrinology 1997138 2227-2232.

22 Saito T, Endo T, Kawaguchi A, Ikeda M, Nakazato M, Kogai T et al. Increased expression of the $\mathrm{Na}^{+} / I^{-}$symporter in cultured human thyroid cells exposed to thyrotropin and in Graves' thyroid tissue. Journal of Clinical Endocrinology and M etabolism 199782 33313336.

23 Kawaguchi A, Ikeda M, Endo T, Kogai T, Miyazaki A \& Onaya T. Transforming growth factor- $\beta 1$ suppresses thyrotropin-induced $\mathrm{Na}^{+} / \mathrm{I}^{-}$symporter messenger RNA and protein levels in FRTL-5 rat thyroid cells. Thyroid 1997 789-794.

24 Uyttersprot N, Pelgrims N, Carrasco N, Gervy C, Maenhaut C, Dumont JE et al. Moderate doses of iodide in vivo inhibit cell proliferation and the expression of thyroid peroxidase and $\mathrm{Na}^{+} / \mathrm{I}^{-}$ symporter mRNAs in dog thyroid. Molecular and Cellular Endocrinology 1997131 195-203.

25 Levy O, Dai G, Riedel C, Ginter CS, Paul EM, Lebowitz AN et al. Characterization of the thyroid $\mathrm{Na}^{+} / I^{-}$symporter with an anti$\mathrm{COOH}$ terminus antibody. Proceedings of the National Academy of Sciences of the USA 199794 5568-5573.

26 Levy O, De la Vieja A \& Carrasco N. The $\mathrm{Na}^{+} / I^{-}$symporter (NIS): recent advances. Journal of Bioenergetics and Biomembranes 1998 30 195- 206.

27 Endo T, Kaneshige M, Nakazato M, Ohmori M, Harii N \& Onaya T. Thyroid transcription factor-1 activates the promoter activity of rat thyroid $\mathrm{Na}^{+} / \mathrm{I}^{-}$symporter gene. M olecular Endocrinology 1997 11 1747-1755.

28 Tong Q, Ryu K-Y \& Jhiang SM. Promoter characterization of the rat $\mathrm{Na}^{+} / I^{-}$symporter gene. Biochemical and Biophysical Research Communication 1997239 34-41.

Received 6 November 1998

Accepted 11 January 1999 